\title{
Gendered Mobilizations against Austerity in Ireland
}

\author{
Pauline Cullen* and Mary P. Murphy
}

This article examines the impact of the economic and social crisis in shaping political agency in women's and feminist organizations in the context of Irish austerity. Examining forms of political agency exercised by women in a range of gendered mobilizations, we isolate examples of defensive agency that seek to protect women's interests from fiscal retrenchment. Despite the damage to gender infrastructure we argue that feminist agency remains crucial to realizing gender equality in public and private decision making. Evidence suggests that in the Irish context, despite deep austerity, gendered forms of mobilization are resisting retrenchment but are doing so in an absence of intersectional solidarities.

Keywords: Ireland, crisis, gender, feminist organizations, defensive political agency

\section{Introduction}

$\mathrm{T}$ he social consequences of the Irish economic and social crisis have been severe with a 7 per cent or $€ 30.1$ billion reduction in public expenditure over six years, the impact of which has exacerbated existing gendered inequalities and intensified the neoliberal Irish model (Murphy and Dukelow, 2016). While there have been tax increases (Callan et al., 2013), Ireland remains a low-tax regime marked by increased privatization of public services. Austerity measures have seen the introduction of user charges, a more conditional activation regime and more dualization in the labour market (Murphy and Loftus, 2014). Other hallmarks of austerity include declining social protection and reduced investment in health, education, housing, social, and care, local and community development services. The consequences have been severe for women (Barry and Conroy, 2013): studies find a gendered impact in successive austerity budgets (Barry and Conroy, 2013; Murphy, 2014; Murphy and Loftus, 2014; Rubery, 2013; TASC, 2012). Tax and benefit changes have reduced the individual income of women more than men, particularly among those on lower incomes (Keane et al., 2014).

In this context we examine the impact of the Irish crisis on the forms of gendered agency exercised by women in civil society and feminist organizations, and explore challenges faced by the feminist movement and groups mobilizing in implicit ways on women's interests in what we refer to as gendered mobilization.

We first contextualize this study by exploring recent scholarship about gendered mobilization and change. We then detail our methodology and conceptual framework. Next we outline the degree to which the crisis has damaged Irish gender infrastructure and feminist organizational capacity. We then present four case studies of gendered mobilization in the form of defensive gendered campaigns of civil society organizations and trade unions in response to austerity. We analyse the degree to which these campaigns are feminist mobilizations and what they can tell us about gendered and feminist intersectional solidarities.

Address for correspondence: *Pauline Cullen, Department of Sociology, Maynooth University National University of Ireland, Maynooth, County Kildare, Ireland; e-mail: pauline.cullen@nuim.ie 


\section{Theorizing gendered mobilization resistance and change}

To assess how gendered mobilizations have responded to austerity in the Irish context we draw upon work that has interrogated the relationship between neoliberalism, gender inequality and feminist mobilization (Fraser, 2013; McRobbie, 2009; Newman, 2013). This work generated important insights into the constraints but also the opportunities that shape feminist efforts to challenge neoliberalism (Eschle and Maiguashca, 2013; Newman, 2013; Walby, 2011). Longer-term trends of managerialism have generated depoliticized contexts where new public-management logics pull gender-equality advocates into service-level agreements that act to narrow and moderate advocacy efforts. An audit culture has resulted in an inhospitable climate for progressive feminist politics (Kantola and Squires, 2012); specifically, a reliance on evidence-based gender expertise requires funding stability and has been linked to the redirecting of feminist goals. For some, feminist ideas have become entangled in neoliberal projects (Fraser, 2013; McRobbie, 2009). From this perspective, marketized feminism has become complicit in capitalist processes (Fraser, 2013; Kantola and Squires, 2012) and a form of postfeminism has emerged that emphasizes empowerment and choice but conceals new forms of gender regulation and displaces radical feminist ideas (McRobbie, 2009).

Other analyses support a less pessimistic account, arguing for a more nuanced notion of resistance and radicalism that emerges from shared projects generated through encounters between feminist and other activist claims (Eschle and Maiguascha, 2013; Evans and Chamberlain, 2014). Although acknowledging the constraints that exist when feminist justice claims are advanced in populist political and movement contexts (Emejulu, 2011a, 2011b), we argue in agreement with Newman (2013) for exploring the situated agency of women as evidence of how women work the contradictions of neoliberalism in real life, in their work and in activism. Gains, even if temporary or partial, must be acknowledged. This analysis also speaks to research on gendering change (Benshop et al., 2012) in highlighting the role of gendered mobilization (in all its forms) in manipulating the paradoxes generated by neoliberalism and forms of new public management in the context of austerity.

Calls for more inclusive and 'intersectional' approaches to understanding gender inequality and feminist mobilization (Crenshaw, 1989) distinguish between feminist movements, women's movements and women in movements. Efforts to delineate different forms of the feminization of resistance acknowledge the diversity of women's interests and claims. For feminist political theory the challenge is how to construct 'women' in such a way that recognizes differences, avoids essentialism and builds solidarity and common purpose across the conflicting or competing interests and experiences of different kinds of women. These constructions matter because they have important implications when 'women' seek to organize to advance particular political interests derived from their identity and their experiences of inequality (Emejulu, 2011a, 2011b). Some women's movements are distinctly and proudly feminist; others avoid the term even while consciously or unconsciously adopting feminist practices and attitudes. Other mobilizations, often dominated by women, explicitly employ universal identity categories such as mother and woman in strategic ways to secure their goals (Emejulu, 2011a; Goss and Heany, 2011). Some of these tactics or efforts have weakened movements, narrowed their goals and closed down opportunities for building intersectional and solidaristic forms of resistance (Motta et al., 2011). In addition, a range of activist communities on the left, such as trade unions, anti-poverty and anti-austerity movements populated by women (but often led by men), perceive feminist-labelled arguments as marginal or irrelevant to their struggles (Motta et al., 2011). We argue for an avoidance of rigid distinctions, shifting our focus from narrowly defined women's movements and feminist movements to a broader, more encompassing 'gendered mobilization' and a more open framework for capturing the empirical realities of today's social movements and civil society resistance on women's interests (Irvine et al., 2015). This wider lens aims to capture the ways in which movements and campaigns that are not explicitly feminist may be grounds for making demands for women's and feminist interests.

The single-issue campaigns detailed here may or may not evoke a feminist framework or be overtly gendered, but may have important gendered implications. Thus, when women participate in such mobilizations - whether or not they are explicitly mobilizing as women, mothers or workers - they 
can further feminist goals. Feminist organizations may in turn decide to deemphasize their involvement in an allied campaign or conversely work to amplify a feminist frame or decline alliances for strategic reasons. Using the term 'gendered mobilization' captures this range of mobilization and the political agency exercised by feminist actors and by women mobilizing in single-issue and employment-based campaigns in the context of austerity.

\section{Methodology}

Before introducing and analysing four Irish case studies this section briefly describes the methodology used to analyse the different examples of gendered agency and mobilization. This study draws primarily on secondary sources and primary data collected from public sources including government and non-governmental organizations (NGOs), media websites and publications. It analyses 12 semi-structured interviews conducted over 2014 and 2015 with key policy officers who are selfdescribed feminist actors, as well as other activists and organizational staff members of trade unions and representatives of civil society organizations. We draw directly from interviews with two tradeunion officials, two policy officers in a migrants' rights organization, three staff members of a national women's organization, a former director of a lone parents' organization, two government officials, a leader in the Domestic Workers Action Group (DWAG) and a politician and feminist activist. ${ }^{1}$ In addition the research draws on the author's instances of participant observation and reflection on organizational challenges to the gendered impact of austerity measures at the national level.

Our conceptual framework is also informed by work that has examined the relationship between citizen engagement, civil society and political structures in a neoliberal context at a time of crisis (Sanchez-Salagado, 2013; Woodward et al., 2014). This work also speaks to the relatively few efforts to document specifically how feminist organizations have responded to the crisis and related austerity (Annesley, 2012; Cullen, 2014). We draw in particular on specific conceptual frameworks that enable complex understandings of the organizational nature of activism in times of crisis, including Ellison's (2000) assessment of the changing nature of citizenship and civil society in the late modern neoliberal context. Ellison defines citizenship as characterized by individualism and fragmentation into a series of 'temporary solidarities', which take the shape of 'a social politics characterized by "defensive" or "proactive" forms of engagement' (para 1.2). Defensive engagement means citizens defending themselves against the erosion of their social rights created by the persistent and occasionally dramatic demands of rapid economic, social and political change. This 'active defence' happens through interventions in the fragmented social politics of the public sphere and often in ways that undermine solidarity. Defensive protest is more likely to be organized defensively around social divisions already shaped by existing policy discourses, for example welfare provision.

We are also influenced by arguments that broadening the definition of who represents women and what their interests are can work to exclude disadvantaged or marginalized women (Dovi, 2015). The value of these analyses for the cases examined here is the emphasis on looking beyond explicitly feminist groups to locate women's resistance to austerity. There is also value in evaluating whether claims advanced by organizations and campaigns that aim to improve the lives of women as a status group also address class and other inequalities among women (Dovi, 2015). Gendered mobilization then becomes in part an empirical question posed to forms of resistance and protest: was there a significant presence of women? To what degree was the campaign gendered? What versions of women's interests were advanced? Did the campaign exclude or have unintended or harmful consequences for some women? Did actors ringfence the space for women's interests, avoid or include explicit feminist claims? What role did broader anti-austerity frames play and did they provide room for a gendered analysis, feminist claims and/or an intersectional perspective? These questions guide our analysis.

Posing these questions to the campaigns considered here also requires a conceptualization of the form of political agency employed in gendered mobilizations. Political agency in this regard is not understood simply as women's actions in the public sphere in a homogenous way (Robson and Spence, 2011). Rather, political agency within gendered mobilizations is understood as constituted in complex and competing ways by different groups of women in different contexts. This 
understanding allows for analysis and critique of those actions that exclude or silence women, including poor, working-class, ethnic-minority and migrant women, while offering the possibility that different types of women may also encounter each other, articulate their (often conflicting) interests and take collective action (Emejulu, 2011b). Different examples of such processes or exclusion and coalescence are included in the case studies below. The exercise of collective political agency in gendered mobilizations may involve the conscious deemphasis of feminist frameworks or implicit (if unacknowledged) forms of gendered analysis, forms of essentialism and feminist assessment.

There is insufficient acknowledgment of instances of feminist organization and gendered resistance in the Irish context. Such resistance demonstrates a relatively sophisticated understanding of Irish political culture and in some instances campaigns succeeded at rolling back cuts or protecting key supports (albeit in the context of overall crisis budgets). Central to our analysis is a series of case studies of defensive gendered resistance to Irish austerity cuts that serve as examples of circumscribed and pragmatic alliances (Conway, 2013) that emerged between Irish civil society organizations, trade unions and feminist groups resisting in defensive campaigns specific crisis-related gendered cuts. The case studies illustrate the dynamics of collective mobilization between a diverse range of organizations that, through the process of resistance, constitute various constructions of women's and gendered interests.

\section{Austerity and gendered mobilization}

Irish civil society organizations and feminist actors operate in the context of Irish political culture, ideology and institutions. Ireland is characterized by its peripheral location, a conservative and rural culture, and Catholic deference. These key factors influence the political culture of a relatively passive Irish civil society. More find explanation for civil society's relative passivity in the 1920s civil war and an absence of class cleavage in Irish society, leading to the under-formation of the Irish political left (Murphy, 2012). The nature of institutions also informs attitudes to protest and may explain the predominance of defensive-style protest and the lack of a more strategic and long-term offensive orientation. Political culture interfaces with a multi-seat proportional electoral system that perpetuates clientalism, localism and personalism. The corporatist nature of the Irish state also has the capacity to coopt or silence civil society. Key organizations have participated in a corporatist arrangement with the state (social partnership), which has left a legacy of interdependence between the state and civil society (Murphy, 2012).

State-civil society relations are a key element in the construction of gender regimes, and in this case Ireland's strong male breadwinner model has shaped public policy and citizenship for Irish women. Women's place was understood to be within the home, while participation in the labour market was traditionally discouraged. Gender inequality in Irish politics has been well documented. Only 5.4 per cent (262 of a total 4746) of parliamentary seats filled since 1918 have been occupied by women while between 1922 and 2012, 22 women held ministerial posts (Buckley and McGing, 2012). The absence of women in the political world is reflected in the wider economic and public sphere where women are significantly underrepresented in Irish media, rarely appear as commentators on economic and political issues and are often specifically marginalized in debates and analysis of the economic crisis ( $\mathrm{O}^{\prime}$ Brien, 2014). All of this confirms the existence of a 'patriarchal dividend' (Connell, 2011) of prestige, status, power and male networks that maintain the absence of women in Irish political and broader public life (Kirby and Murphy, 2011). It is in this historical context that the impact of gendered austerity measures on the organization of feminist and women's advocacy for change and support services needs to be understood.

Recent scholarship suggests that Irish civil society has become more muted over the last decade as the state took a more proactive role in coopting civil society and shaping its direction (Kirby and Murphy, 2011). Such dependence has been sharpened by austerity and has created vulnerabilities across civil society and community-development sectors. The predominant state feminist organization the National Women's Council of Ireland (NWCI) experienced a 35 per cent cut in funding in 2012, justified by the state on the grounds of prioritizing front-line service provision over advocacy 
(Harvey, 2014). Likewise women's refuges and shelters that provide domestic violence and childcare services experienced cuts of up to 40 per cent to their funding and saw remaining funding restricted to service delivery, so that policy and advocacy work has diminished (Harvey, 2014). Many women's organizations feel suppressed or inhibited from dissenting against government policy, while a competitive tendering system for community-development projects has increased competition between organizations seeking to retain staff and services (Harvey, 2014). For some feminist groups like development agency Banulacht and community-development group Kilbarrack Local Education for Adult Renewal (KLEAR), the combination of cuts and funding restrictions left them so unable to meet their core objectives that they closed projects rather than accepting disempowering terms and conditions ( $\mathrm{O}^{\prime} \mathrm{Neill} 2009$ ).

The gender and equality infrastructure has also eroded as a result of austerity. The Equality Authority and the Irish Human Rights Commission (IHRC) experienced budget cuts between 2008 and 2009 of 43 per cent and 24 per cent respectively, and were subsequently merged in 2014 into a new Irish Human Rights and Equality Commission (IHREC). The Women's Health Council and the Crisis Pregnancy Agency were closed and weakened respectively, while important thinktanks that published work on women, families, employment and poverty - the Combat Poverty Agency, the National Consultative Committee for Racism and Interculturalism, and the National Economic and Social Forum - were closed over the 2009-10 period.

Government austerity strategies focused on public expenditure cuts as the primary tool to manage fiscal correction; these had specific gendered implications (Rubery, 2013). Public-sector job cuts have gendered impacts: women comprise 65 per cent of these jobs and over 80 per cent of some health and education sectors of the Irish public service (Barry and Conroy, 2013). Reductions in social expenditure have also contracted key income supports and social services, many of which have gendered patterns of use. In turn this places pressure back onto communities and families where women traditionally serve as care buffers and managers of much-reduced family budgets, exemplified in the fact that 63 per cent of lone parents in Ireland experienced deprivation in 2013 (CSO, 2015). The Irish economy is characterized by low pay with 41.8 per cent of men in Ireland earning $€ 20,000$ or less; 50.3 per cent of Irish women in Ireland earn below this amount (CSO, 2014).

\section{Gendered mobilization against austerity: resistance to social security cuts}

This section focuses on civil society campaigns directed at social security budget changes that specifically impact on women, changes to lone parents' payments and cuts to child benefit (CB) (Murphy, 2014). The case studies examine how gendered mobilizations and women's interests are constituted through political agency exercised in feminist organizations and a diverse range of civil society groups. The history of the Irish women's movement is marked more by fragmentation than by cohesiveness. Networked to, but existing beyond, mainstream state feminism is an entire realm of political practices that at times functions as only implicitly feminist (Connolly and O'Toole, 2005; Cullen, 2008; Cullen and Fischer, 2014; De Wan, 2010). State feminism is defined here as national and local bodies with a function with regard to gender equality and civil society organizations that advocate from a feminist perspective and are reliant on state funds and contracts. On the ground, feminist practices exist in a diverse array of local and community groups, activists, practices and ideologies. Activists practice 'movement activism', where groups and individuals coalesce into campaigns at particular moments for important issues (De Wan, 2010; Cullen, 2014). Trade Union TV (Geraghty, 2012) shows a rich record of women's agency in public protest over the crisis, with women dominating many lo$\mathrm{cal}$, national and sectoral protests. The following two examples of gendered mobilization, against cuts to lone-parent payments and $\mathrm{CB}$, are chosen specifically because they demonstrate strong and partially successful gendered political agency.

\section{'Seven is Too Young' campaign: the defence of lone-parent allowance}

One Parent Exchange Network (OPEN), a state-funded national self-representative network of almost 100 local lone-parent groups, allied with others to campaign against plans by the state to align the 
main support for lone parents, the one-parent family payment (OFP), with job-seeker's allowance (JSA) when a lone parent's youngest child reached seven years of age. This cut would reduce earned income disregards for lone parents at the same time as increasing employment conditionality. In response to the proposed cuts OPEN launched the 'Seven is Too Young' campaign, arguing, 'this unnecessary reform is ill-fitting a government which has both international and national obligations to reduce poverty, look after children and protect the most vulnerable' (OPEN, 2012, p. 2). OPEN secured crowdsourced funding for an innovative bus-stop advertising campaign and worked with other groups including the state-funded feminist NWCI (of which it was a member) and a broadbased alliance of children's-rights groups (the Children's Rights Alliance [CRA]) to target politicians' local constituency offices (NWCI, 2014). OPEN's campaign promoted a strong populist, pro-family and pro-child message emphasizing the link between the proposed cuts and child poverty. OPEN and its allies maintained their commitment to activation as a policy response that would allow women in poverty with children to move from welfare to work. However, their support for activation was accompanied by a demand for the provision of state-supported childcare provision. This was emphasized by a member of OPEN: 'we were anxious not to go backwards on this, we wanted to stress the right to work as well as the right to care'. Feminist support of the campaign (in the guise of the NWCI) suggests a gendered focus; however NWCI played a relatively minor role, a function of competing pressures and priorities and the management of scarce resources in the context of austerity.

The wider campaign involved a number of diverse civil society organizations, including SPARK (Single Parents Acting for the Rights of Our Kids), a smaller self-organized and more militant group of single parents. SPARK was founded in 2011 as a response to the proposed cuts and is loosely associated with the hard-left People Before Profit electoral alliance. SPARK contributed to the campaign with a more direct-action focus, organizing a 2013 protest that directly confronted Labour Party politicians. SPARK also conducted a lively Facebook campaign that mobilized parents and children to attend their protest events and to confront individual politicians in local contexts. Posters explicitly invited 'trade unions, one-parent family organizations, local groups and individuals from all over the country to join them'(SPARK, 2013). These campaigns drew upon direct-action protest and were populated predominantly by women and children outside government offices and parliamentary buildings. SPARK's contribution to the 'Seven is Too Young' campaign offered a less explicitly gendered lens: their organization description states that 'SPARK is for anyone raising a child or children alone; we are against the recent changes to social policies that negatively affect our children and their futures' (SPARK, 2015). Their opposition to the cuts contained no compromise on wider welfare reform and reflected their ties to hard-left anti-austerity political organizations, illustrated in a 2014 campaign centred on a slogan 'Top cats get fatter — but our children still matter'. ${ }^{2}$ This absence of a feminist framework is consistent with traditional strategies of the left that make it less hospitable to gendered claims. In this regard relationships between OPEN and SPARK were constructive but also reflected their respective origins and associated political organizing tactics; an OPEN staff member described how 'we would give SPARK meeting space in our offices, things like that, but they would do their own thing'.

The overall campaign engaged with government electoral commitments to protect the vulnerable and was at least partially successful in mitigating the cuts to OPFP (Murphy, 2014). However in spite of some state rollback a senior manager of OPEN commented 'I do not see any even limited victory. We were totally defeated in what we wanted for lone parents; before the crisis it looked positive, we thought we might even end cohabitation - now it is all lost'. OPEN are now dormant, an outcome of legacy issues, the direct impact of budget cuts, the loss of local affiliates as local lone-parent groups closed as a result of the crisis, and the disempowering impact of a sustained assault on lone parents as a constituency in receipt of state support. OPEN's vulnerability stemmed in part from its dependence on state support. This resonates with Fraser (2013) characterization of the neoliberal state's cynical embrace of civil society and her critique of liberal feminism's ambivalence towards this. SPARK, as a more loosely configured entity without ties to state funds, continues to organize and campaign, albeit with a very poor resource base and primarily on Facebook and through social media. 
The space for gendered political agency also continues to shift, evidenced by the decision of a national-level service group working with lone parents, One Family, to disaffiliate from the national feminist organization, the NWCI. On the other hand, feminist political leadership has been demonstrated in a 2015 Civic Forum on Lone Parents led by a prominent femocrat, ${ }^{3}$ Senator Katherine Zappone. Zappone facilitated a think-in for remaining lone-parent groups and feminist academics to mobilize and campaign against further benefit cuts (Civic Forum, 2015) and demonstrated solidarity, working with other independent politicians to submit a motion to the Irish senate (Seanad Eireann) on 9 April 2015.

\section{The defence of universal child benefit}

While the crisis occasioned significant cuts to $C B$, unlike the UK gendered defensive agency ensured that Ireland survived six years of austerity budgets without taxation or means-testing of this universal payment (Campbell-Barr and Coakley, 2014). In the period leading up to and after the 2009 budget both the NWCI and the CRA were at the forefront of an alliance opposing any cuts in CB (Coakley, 2014). A NWCI (2009) briefing paper set the scene and championed CB as a universal gendered payment that directly supports mothers, assists childcare costs for working mothers and acts as a payment for those who care in the home. A subsequent membership survey conducted by NWCI showed $\mathrm{CB}$ to be a critical part of family income, with 45 per cent of respondents attesting cuts in CB would be a 'financial disaster' for their families (NWCI, 2010). Coakley (2014) notes how a CRA 2009 prebudget submission strongly opposed any cuts, tax or means-testing of CB and framed $\mathrm{CB}$ as a valued child-centred payment that supported universalism and horizontal distribution. In this submission the organization pointed directly to the electoral fallout: 'taxing or means-testing CB would be deeply and politically unpopular' (CRA, 2009, p. 6).

A Protest Against Cuts to Child Benefit (PACUB) campaign, initially established in April 2008 to fight cuts to other supports, brought the NWCI and the CRA together in a Facebook campaign in 2011, followed by organized protests and a 2012 petition with 28,000 signatures. A key NWCI worker described how the organization had initially sought to work in wider alliances: 'we joined wider antiausterity campaigns but we could not get them to talk about gender and some of the anti-poverty organizations did not even support our calls not to cut child benefit'. Campaigners - mostly women and children - gathered outside the government buildings in a mass of prams and placards, communicating a strong maternalist message about the implications of cuts for child wellbeing and women's capacity to 'mother' their children (Campbell-Barr and Coakley, 2014). The NWCI, who supported the campaign, had reservations, stating they were 'nervous of diluting key messages' and reflecting that 'winnable media-friendly campaigns often carried the most danger of tactical dilution'. These campaigns spoke directly to the political system, holding it accountable to previous commitments made to protect the vulnerable, and ultimately proved successful in restraining the state from taxing or means-testing this universal payment (Coakley, 2014). The message about the electoral salience was clearly heard as both the 2015 and 2016 budgets introduced an increase of $€ 60$ in CB per child per annum, effectively restoring the primary CB payment to 2011 levels. The Tánaiste (deputy prime minister) subsequently guaranteed the maintenance of the still-universal CB.

These two case studies reflect elements of conscious and reflexively defensive agency (Ellison, 2000), albeit within the constraints of Irish neoliberal political culture. Notably, interview data confirm that the campaigns detailed earlier ( $\mathrm{CB}$ and 'Seven is Too Young') consciously limited the range of alliances they worked with in order to maintain an explicitly gendered focus and carefully calibrated their forms of engagement to tactically manage political relationships - which is important in the context of cuts to statutory funding.

The strong maternalist message of both campaigns suggests more association with an essentialist construction of women's agency than with a specific feminist framework. Maternalist claims, or the use of concerned motherhood, allows women to organize as women but risks deepening the populist claims of the discourse and promoting traditional social relations (Emejulu, 2011a). However, from another perspective 'activist mothering' - as coined by Naples (1992) — can be seen as a form of 
politicization that ties motherhood with a politics of resistance at the community level and that could potentially accommodate feminist claims while resisting essentialism. Both campaigns amplified a maternal frame yet one connected to a more 'activist mothering' orientation that embedded calls for economic equality and employment for lone parents and a combination of 'women as caregivers' and 'women as rights bearers' (Goss and Heaney, 2010, p. 29). Campaign leaders appeared quite conscious about the tensions in using essentialist frames: a NWCI spokesperson commented, 'we tried to keep the message complex, to make sure the demand for childcare was heard'.

For the CB campaign this can be considered as a form of defensive essentialism drawing on an entitlement of mothers to economic support. This approach lacked a more nuanced or tactical form of essentialism, seen in the lone parents' campaign that advanced claims for women as agents seeking support for economic independence beyond a traditional maternal role.

The two campaigns also differed in terms of the universal versus the targeted nature of the benefits under threat. The restoration of the universal CB payment to 2011 levels was strongly resisted by Barnados and other child-poverty campaigners, who argued that such an approach would do little to address the reality of child poverty, which had doubled over the crisis. There is no consensus about the most effective use of child income supports to tackle child poverty (Coakley, 2014). However, these gendered campaigns pushed to retain this universal payment for all women rather than engage with calls for a more targeted approach toward the poorest families. This represents ambivalence towards a class analysis alongside the strong maternalist frame as a form of short-term defensive essentialism. In this sense the gendered political agency employed in the CB campaign engaged less with the interests of poorer women and children. In both of these campaigns, defensive gendered agency was short-term and aimed at retaining benefits. The pragmatic and instrumental nature of the exercise limited the generative possibilities for a deeper and more intersectional engagement on the gendered and classed impacts of austerity. The maternal framework, while allowing women to organize as women and identify as mothers fighting for their families' futures, reinforced populist claims that were largely consistent with the populist tendencies of Irish political culture.

\section{Gendered mobilization in trade unions}

The 1970s to mid 1990s saw an intense gender struggle in the Irish trade-union movement. By the mid 1990s gender interests were partially accommodated in mainstream union activity, even while some unions maintained patriarchal attitudes (Quinn, 2004). Roche et al. (2011) note how the recession has debilitated trade unions and shifted the class and gender composition of members with new members more likely to be female, married, older and home owners. As Quinn (2004) concluded, 'the patriarchal trade union is continuing in Ireland and what change has occurred may be marginal rather than deep rooted' (p. 665). A 2013 Irish Congress of Trade Unions (ICTU) audit shows a significant gap between the number of women and men in key leadership positions within trade unions, with little divergence between 2010 and 2013 except for the number of women in 'officials' grades (from 33 per cent to 52 per cent), explained in part by the degree to which women filled new 'trade-union organizer' jobs (ICTU, 2013). Despite the recent efforts of trade unions to pursue gendered campaigns, trade unionism in Ireland remains an industrial-relations issue considered from a singularly masculine perspective. Having set this context we consider how trade unions can work as spaces for gendered mobilizations, albeit with uneven consequences for different categories of female workers. The following two case studies detail how firstly unionized care workers employed defensive agency against cuts in state home care budgets and secondly how various organizations came together to develop a campaign on the wider terms and conditions of home-care workers.

Husso and Hirvonen (2012) examine the gendered effects of changes in public-sector care work in the context of neoliberal reforms. Until the turn of this decade, Irish home helps were predominantly public-sector employees funded directly by the central government and employed by the administrative agency for health services in Ireland, the Health Services Executive (HSE), to deliver elder care to people in their own homes. Since 2011 such care was increasingly privatized with up to 150 private companies in the sector, the largest eight of whom shared over $€ 156$ million worth of public-sector 
tenders over the period 2011-14. The home-care industry has an estimated value of $€ 340$ million and employs up to 12,000 workers in the public sector and 6000-8000 in the private sector (MRCI et al., 2015). An emerging trend is the use of live-in carers (often migrants) to provide elder care. This bifurcation of the home-help sector means approximately 50 per cent of home helps are unionized and employed by a public-sector agency and 50 per cent in the private home-care sector; the latter are more likely to be migrant workers and have not been unionized. The Services Industrial Professional and Technical Union (SIPTU) is the largest organizer of home-care workers with 10,000 HSE (public) employed members.

In 2012, there was no legislation regulating home care in Ireland and both sectors operated through the use of low-hour 'if and when' contracts that committed neither employer nor employee to a set number of hours. Paid only for 'time on task', the home-care service model in both sectors was characterized by low-quality work experience, income insecurity and employment instability (MRCI et al., 2015). Irish home-help budgets were cut by 500,000 home-help hours in 2012, with proposals to reduce a further 600,000 hours before the end 2013 (Oireachtas, 2012). Irish gendered mobilization on paid home-care work developed in two sequential campaigns. The first response to these cuts that we will examine is the 'Time to Care' campaign, while the second is the DWAG campaign.

\section{‘Time to Care' campaign}

The gender composition of home-help workers in Ireland is 98 per cent female. However, the Irish trade-union movement has found it difficult to promote links between low pay and female employment, particularly in paid care and domestic work in the home. Campaigns on the living wage and fair employment were described by a female trade unionist as 'raising awareness of the system and the sharper employment practices, much of which affect women workers, but we do not explicitly state that'. From the other perspective a female union official offered a critique of feminist organizing for low-paid women, asserting that 'there is a narrative around entrepreneurial women and other women as victims, but there is no clear feminist narrative of what constitutes a fair workplace'. Trade-union officials also identified a lack of class solidarity among unionized women, employing home helps or domestic workers themselves. A female trade unionist commented, 'we were aware that many of our members employed domestic workers, so we tried hard to communicate to our members that this was about rights for domestic workers but also obligations for the woman employing the domestic workers'.

Husso and Hirvonen (2012) stated that 'gendered meanings and identities significantly shape the way workers experience, understand and interpret the work they do and the kind of agency they consider to be possible for themselves' (p. 30). This is evident in the way the organization of this type of care work shapes and draws out workers' personal qualities as carers - for example, in the description of workers' 'commitment to caring for their clients' (MCRI et al., 2015, p.4). The defence of Irish home helps' pay and conditions happens in the context of gendered patterns of emotional involvement in care practices and where a strong ethic of care informs political responses to austerity. A trade-union official recalls mobilizing home helps: 'the women were motivated by the idea that their clients would benefit if workers were treated better; when the workers were talking to the media we had to remind them to talk about themselves as workers, not just their clients'. Care workers resisted cuts to home-help budgets without withdrawing their labour, which was seen as an unacceptable tactic in terms of its implications for those for whom they cared.

This campaign was also influenced by the efforts of Ireland's largest trade union, SIPTU, to innovate new ways of organizing. A trade-union official described how the home-help campaign was identified as central by union leadership; the sector was seen to be central, a growing industry'. SIPTU members mobilized throughout 2012 in response to cuts in (HSE) home help budgets and the use of no-hour 'if and when' contracts. As detailed earlier, home-help carers were circumscribed by the reality of 'emotion work' (Hochschild, 1983), where the interconnectedness between the caregiver and care receiver ruled out more traditional forms of trade-union agency involving the withdrawal of labour. A trade-union official described how the female home helps had evolved from 
charity models of care: some older women who worked part-time as home helps 'took some time to identify even as workers'. Working with them necessitated a different form of creative mobilization more commonly associated with NGOs and social movement groups. An extensive campaign entitled the 'Time to Care' campaign creatively used direct-action protest involving symbolic coffins, music and pipers to encourage mobilizations. Female care workers in red $\mathrm{t}$-shirts petitioned and lobbied local political constituency offices, targeting the Taoiseach (the Irish prime minister) in a protest campaign. 'Time to Care' represents a significant shift in the style of language used in trade-union campaigns, with a strong gendered element in the choice of words and phrases. Victory ensued when privatization was rolled back and new public contracts were secured in a Labour Court recommendation in September 2013. ${ }^{4}$

While 'Time to Care' was a creative gendered response to austerity's impact on both social reproduction and productive work, the campaign also employed forms of gendered agency that promoted not a reflexive or tactical use of essentialism but a strong essentialist notion of this predominantly feminized care-work sector. There was no evidence of feminist framing; indeed, as a trade-union official described, 'the women still would not use feminist slogans, nor would they use the language of trade unions'.

\section{MRCI's Domestic Workers Action Group}

The 'Time to Care' campaign offered insights for those specifically mobilizing to support migrant women in paid domestic and care work. The Migrants' Rights Centre of Ireland (MRCI) had previously identified issues facing migrant care workers as a long-term campaign goal and had established DWAG in 2000. Led by minority and migrant women, DWAG uses a community-development model to empower home-care workers to self-mobilize on employment issues.

The successful outcome of the 'Time to Care' campaign - the shift away from privatized home help provision - also negatively affected migrant women, who predominate in the private employment sector. While there was awareness of different work hierarchies in the trade-union movement it was not anticipated that migrant workers would not only lose hours in the reversion from private to public sector but also experience poorer terms and conditions of employment in the private sector. These unintended consequences demonstrate the limits of the campaign and the difficulties of maintaining intersectional solidarities across and between working-class and migrant and ethnic-minority women workers (Emejulu and Bassel, 2015). 'Time to Care' was a form of gendered mobilization and political agency that suppressed different hierarchies around gender and race in favour of mobilizing a cohesive notion of women as care workers opposed to austerity-based cuts. This confirms the difficulties trade unions have with the complex intersectionality that characterizes low-paid feminized work.

The union originally appeared reluctant to support the specific interests of ethnic-minority and migrant women, and relied instead upon the organizations representing migrants - the MRCI and the DWAG — to mobilize and build cooperation on these issues. This initial cooperation was characterized by a member of the MRCI and the DWAG as 'very difficult; domestic workers felt they were written out of the consultation process with the unions; in concrete terms they did not offer much support and the relationship broke down'. Cooperation has evolved between the unions and the DWAG, with a successful joint campaign for Irish ratification of the International Labour Organization Domestic Workers' Convention in 2014. However, the relationship remains characterized by the DWAG as one where domestic workers have to act continuously to maintain their visibility.

The 'Time to Care' campaign and SIPTU had originally contacted MRCI to organize focus groups to collect data on the experience of Irish home helps. This research data revealed a significant division between Irish working-class women who were state-employed home-care workers (seen as having superior conditions) and ethnic-minority and migrant women working for poorer conditions in the private home-care sector (employed by for-profit and voluntary organizations). As a staff member from MRCI commented: 
State-employed home helps are mostly working-class Irish women; migrant women were more likely to be on private contracts with lesser wages, so this is a form of hierarchy with two carers working in the same home on different levels of pay and conditions.

The consultation also generated feedback from a small number of migrant home-care workers about the existence of racial tensions.

Data from interviews with those involved with the campaign also suggested that home-help workers employed by private contractors who had supported the 'Time to Care' mobilization were subsequently frustrated by the uneven outcomes generated through the campaign. As one of the MRCI team recalled, 'there was a lot of frustration with the union: some workers felt they had been used as pawns in a campaign that only benefited the state-employed carers'.

In a subsequent and related campaign led by the MRCI, DWAG has sought to regulate the privatesector home-care industry and protect against increased privatization of the sector (MRCI, 2015). To build a form of political intersectional solidarity, the MRCI invited both the feminist NWCI and the trade union SIPTU to occupy positions on an advisory group. Both have been active in the campaign, as were the non-profit Carer's Association who both represent and employ home-help workers. This form of gendered mobilization has involved integrating the experiences of migrant and ethnicminority women directly into the process of constructing recommendations for regulation of the entire sector. This effort to approach the issue from a multi-stakeholder perspective is recognition of the cleavages between home-care workers, particularly those employed in different contractual situations. It also directly engages with the constraints that state contracts have on NGOs such as the Carer's Association in efforts to provide high-quality care and decent employment.

The challenge for campaigns such as these remains the resistance of the private sector to regulation and the difficulties in making a case for the link between high-quality care and decent employment conditions for women in the context of austerity.

A form of strategic essentialism structures this campaign, which aims to shift the issue away from simply a migrant-worker issue to one of women's work linked to quality affordable care for all. As the MRCI commented, 'care is intrinsic to life; we all need care, we want to build a movement of all those dimensions and to really see that migrant workers can be at the fore pulling this together'.

From the MRCI perspective, these campaigns face inherent difficulties in bringing women together when migrant and ethnic-minority women remain at the bottom of a hierarchy of employment conditions. Interviews with trade-union officials also suggest increased awareness of the need to identify common interests across home helps employed in the public and private sectors, but also acknowledge 'the constant tension in moving forward'. The effort here to both acknowledge the distinctive challenges facing minority women while seeking the support of all women employed in this sector indicates an attempt to evolve a form of gendered mobilization and gendered political agency that is more open to intersectional justice claims. Yet the challenge for such campaigns remains in communicating that poor terms and conditions in care work is 'a women's issue' that extends beyond migrant women. At the same time, from the migrant domestic workers' perspective, a migrant activist in the campaign described how:

We don't feel a strong connection to feminism as we see that as an elite thing where we are at the bottom. Often times the person in charge is a woman. We also understand that low-paid women need affordable care, but you can't let one group of women succeed on the back of another group of women.

\section{Discussion and conclusions}

Our analysis of these case studies of gendered mobilizations was guided by a number of analytical questions introduced in the methodology section. Table 1 analyses the four campaigns. The second column assesses the nature of the 'frames' used to advance agendas and differentiates different types of essentialism: strong, defensive, tactical and strategic. The third column charts the nature of alliances, assessing the degree to which they are exclusive to the single issue, whether they expand beyond feminist or women spaces and whether there is evidence of alliance building. The fourth 
Table 1: Four case studies of Irish gendered mobilization: framing, alliances and outcomes

\begin{tabular}{|c|c|c|c|}
\hline Campaign & Framing & Alliances & Outcomes \\
\hline Lone parents & $\begin{array}{l}\text { Tactical essentialism } \\
\text { Maternal/children }\end{array}$ & $\begin{array}{l}\text { Largely single issue, } \\
\text { some 'class' interface, } \\
\text { split in women's agency }\end{array}$ & $\begin{array}{l}\text { Limited tactical success, } \\
\text { reinforcement of women } \\
\text { as vulnerable mothers }\end{array}$ \\
\hline Child benefit & $\begin{array}{l}\text { Defensive essentialism } \\
\text { Maternal/children }\end{array}$ & $\begin{array}{l}\text { Strong alliances but } \\
\text { exclusive to children } \\
\text { and women; no } \\
\text { poverty alliance }\end{array}$ & $\begin{array}{l}\text { Limited tactical success, } \\
\text { lack of class alliance } \\
\text { around child poverty }\end{array}$ \\
\hline 'Time to Care' & $\begin{array}{l}\text { Strong essentialism } \\
\text { Care ethic }\end{array}$ & $\begin{array}{l}\text { 'Working-class women', } \\
\text { new trade-union class } \\
\text { alliance, limited but } \\
\text { evolving interface between } \\
\text { trade unions and CSOs }\end{array}$ & $\begin{array}{l}\text { Tactical success, } \\
\text { but unintended consequences; } \\
\text { new intersectional } \\
\text { engagement with female } \\
\text { migrant domestic workers }\end{array}$ \\
\hline $\begin{array}{l}\text { Domestic Workers } \\
\text { Action Group }\end{array}$ & $\begin{array}{l}\text { Strategic essentialism } \\
\text { Quality work } \\
\text { and care }\end{array}$ & $\begin{array}{l}\text { Isolation but over } \\
\text { time intersectional } \\
\text { alliance building }\end{array}$ & $\begin{array}{l}\text { Tactical engagement, } \\
\text { significant work to } \\
\text { develop tactical } \\
\text { intersectional work }\end{array}$ \\
\hline
\end{tabular}

column comments on campaign outcomes and assesses the consequences for future framing of the issue and opportunities for alliance building.

We find that the exercise of collective political agency in gendered mobilizations can involve the conscious deemphasis of feminist frameworks or implicit forms of gendered analysis, tactical, defensive, strong and strategic essentialism and feminist assessment. The cases examined demonstrate how the form of political agency exercised has consequences for the potential and limits of gendered mobilizations in generating new broad-based constituencies focused on gender equality and social justice (Emejulu, 2011a). The challenges facing the exercise of political agency in gendered mobilizations include the vulnerability of state-supported professionalized community development in the context of austerity, the presence of male-dominated anti-austerity leftist spaces, exclusionary impulses in the trade-union movement and the durability of clientalism and populism that characterizes Irish political culture.

Key features of resistance included defensive standalone campaigns, with alliances constructed with like-minded organizations, sectoral-specific strategies particularly fronted by those experiencing cuts, and a manipulation of underlying ambiguities concerning liberal, social democratic and conservative value systems, and in particular electoral threats.

The campaigns against cuts to social-welfare payments for lone parents and $\mathrm{CB}$ - both dominated by women - drew upon differing levels of gendered analysis and specifically maternal and/or familial frames and as such satisfy the definition of gendered mobilization against austerity. The 'Seven is Too Young' campaign exhibited the most explicitly feminist framework. This campaign consciously deployed a tactical form of essentialism, linking the loss of supports to female lone parents with the issue of child poverty. The SPARK campaign developed a stronger class-based approach, with little room for a feminist framework. This was unsurprising in the context of the strong connections between this campaign group and the anti-austerity left, which privileges an anti-neoliberal framework above any other forms of analysis. Ethnic-minority or migrant women were largely absent from both campaigns. The subsequent demise of OPEN illustrated the consequences of the communitydevelopment sector's reliance on state funds in the context of austerity. A similar set of pressures generated from cuts to women's organizations reduced the capacity of the NWCI to lead the campaign. SPARK remains resource-poor and largely reliant on voluntary labour and social media, and campaigns on a range of issues (including homelessness and the imposition of water charges) from a pro-familial and progressive populist anti-austerity framework, indicating the difficulties of maintaining gendered claims within leftist spaces. The CB campaign offered an explicitly gendered 
framing and a form of defensive essentialism; however, its focus on the maintenance of universal payments rather than a restructured and targeted support to the poorest children at a time of crisis belied a reformist rather than a radical gendered change agenda. 'Time to Care' and the MRCI DWAG campaigns deployed strong and strategic essentialism respectively, emphasizing a care ethic in women's work and constructing care work as essential, universal and deserving of quality terms and conditions. These efforts had contradictory outcomes and reflect the tensions that characterize the classed gendered and race-based dynamics of gendered mobilizations.

This account of forms of women's and feminist political agency or gendered resistance to austerity in Ireland lends support to Newman's (2013) call to recognize that political agency exists within a hegemonic neoliberal order, albeit in constrained and sometimes contradictory forms. Aside from the MRCI and SIPTU alliance covered here, joint voluntary-sector and trade-union campaigns are rare, suggesting old tensions between class and gender politics, and emerging tensions in intersectional solidarities. Trade unions - even those that are female dominated - are essentially class-focused, and both feminism and wider intersectional agendas remain underdeveloped even in the context of severe austerity. In addition the use of largely maternal frames to resist gendered cuts to lone parents and CB narrowed the version of women's interests that was advanced and limited the feminist substance of such campaigns. However, we find empirical evidence of effective situated gendered mobilizations that support the idea that feminism and other struggles negotiate multiple projects and contradictions to produce potential lines of fracture within a neoliberalism that is multiple and hybrid in form (Newman, 2013; Walby, 2011).

The case studies included here also explore how political agency in gendered mobilizations in allied and single-issue organizational modes have resisted austerity through contingent and temporary interventions made possible through working the available 'spaces of power' (Newman, 2013, p. 218). In other words, gendered mobilizations against austerity illustrate how neoliberal projects can be partially subverted even if such mobilization exposes tensions in maintaining a focus on gender in broader campaigns. What is remarkable is that relatively strong gendered political agency coexists with the disproportionally negative impact of austerity policies on gender-equality infrastructure, services and supports. However, despite some recent efforts, what remain evident are the limits of gender mobilizations to support marginalized women and promote intersectional solidarity at time of austerity.

\section{Declaration of conflicting interests}

The authors declared no potential conflicts of interests with respect to the authorship and/or publication of this article.

\section{Funding}

This research received no specific grant from any funding agency in the public, commercial or not-forprofit sectors.

\section{Notes}

1. All interviews were conducted between December 2014 and July 2015.

2. See https:/ /www.facebook.com/weareOPEN/posts/10152792075520968.

3. 'Femocrat' is understood as an actor in political office or public administration who aims to influence public policy making through an explicitly feminist perspective.

4. The campaign has been recognized throughout Europe as a rollback of the use of zero-hour contracts and creeping privatization (Hamilton, 2013). The HSE must now initially offer care hours to directly employed home helps before considering the use of private agencies. The new contract curtailed the HSE's use of private, 'for-profit' care companies, which had increased 1639 per cent from $€ 2.3$ million in 2007 to $€ 40$ million in 2012 . However, the legal tendering process for privatized home care is subject to an ongoing legal challenge by private care providers (Whyte and Mitchell, 2015). 


\section{References}

Annesley, C. (2012) Campaigning against the cuts: gender equality movements in tough times. The Political Quarterly, 83, 19-22.

Barry, U. and Conroy P. (2013) Ireland in Crisis 2008-2012: women, austerity and inequality. In Rubery, J. and Karamessini, M. (eds) Women and Austerity - the Economic Crisis and the Future for Gender Equality. London: Routledge, pp. 186-206.

Benshop, Y., Mills, J.H., Mills, A. and Tienari, J. (2012) Editorial: gendering change: the next step. Gender, Work and Organization, 19, 1, 1-9.

Callan, T., Keane, C., Savage, M. and Walsh, J.R. (2013) Distributional impact of tax, welfare and public service pay policies: budget 2014 and budgets 2009-2014. Quarterly Economic Commentary, Winter 2013.

Campbell-Barr, V. and Coakley, A. (2014) Providing choice? A comparison of UK and Ireland's support in a time of austerity. Journal of International and Comparative Social Policy, DOI: 10.1080/21699763.2014.951381.

Central Statistics Office (CSO) (2014) Men and Women in Ireland 2013. Available online at www.cso.ie/en/ newsandevents/pressreleases/2014pressreleases/pressreleasewomenandmeninireland2013/. Last accessed 22 January 2015.

Central Statistics Office (CSO) (2015) Survey on Living and Income Conditions. Available online at www.cso.ie/en/ releasesandpublications/er/silc/surveyonincomeandlivingconditions2013/\#.VMoGnv6sXpq. Last accessed 25 January 2014.

Civic Forum (2015) Report on Lone Parents. Available online at http://senatorkatherinezappone.ie/files/KZLP. pdf. Last accessed 19 August 2016.

Coakley, A. (2014) Families and the economic downturn: the case of child benefit. Administration, 62, 3, 1-7.

Connell, R. (2011) Confronting Equality: Gender, Knowledge and Global Change. Sydney: Allen and Unwin.

Connolly, L. and O'Toole, T. (2005) Documenting Irish Feminisms: the Second Wave. Dublin: Lilliput Press.

Conway, J. (2013) Edges of Global Justice: the World Social Forum and its Others. London: Routledge.

Crenshaw, K. (1989) Demarginalizing the intersection of race and sex: a black feminist critique of antidiscrimination doctrine, feminist theory, and antiracist politics. University of Chicago Legal Forum, 14, 538-54.

Cullen, P. (2008) Irish women's organizations in an enlarged Europe. In Roth, S. (ed.) Gender Issues and Women's Movements in the Expanding European Union. Oslo: Berghahn Press, pp. 83-100.

Cullen, P. (2014) Feminist NGOs and the European Union: contracting opportunities and strategic response. Social Movement Studies: Journal of Social, Cultural and Political Protest, DOI: 10.1080/14742837.2014.965674.

Cullen, P. and Fischer, C. (2014) Conceptualising generational dynamics in feminist movements: political generations, waves and affective economies. Sociology Compass, 8, 3, 282-93.

DeWan, J.K. (2010) The practice of politics: feminism, activism and social change in Ireland. In Hogan, J., Donnelly, P.F. and O'Rourke, B.K. (eds), Irish Business and Society: Governing, Participating and Transforming in the 21st Century, pp. 520-36. Dublin: Gill and Macmillan.

Dovi, S. (2015) The politics of non-presence. Paper presented at the European Consortium on Gender and Politics, Uppsala, Sweden, June.

Ellison, N. (2000) Proactive and defensive engagement: social citizenship in a changing public sphere. Sociological Research Online, 5, 3. Available online at http://www.socresonline.org.uk/5/3/ellison.html. Last accessed 12 March 2015.

Emejulu, A. (2011a) Can 'the people' be feminists? Analysing the fate of feminist justice claims in populist grassroots movements in the US. Interface, 3, 2, 123-51.

Emejulu, A. (2011b) Re-theorising feminist community development: towards a radical democratic citizenship. Community Development Journal, 46, 3, 378-90.

Emejulu, A. and Bassel, L. (2015) Minority women, activism and austerity. Race and Class, 57, 2, 86-95.

Eschle, C. and Maiguashca, B. (2013) Reclaiming feminist futures: coopted and progressive politics in a neoliberal age. Political Studies, 62, 634-51.

Evans, E. and Chamberlain, P. (2014) Critical waves: exploring feminist identity, discourse and praxis in western feminism. Social Movement Studies, DOI: 10.1080/14742837.2014.964199.

Fraser, N. (2013) Fortunes of Feminism: from State-managed Capitalism to Neoliberal Crisis. New York: Verso Books.

Geraghty, P. (2012) Trade Union TV. Available online at www.youtube.com/user/TradeUnionTVIreland. Last accessed 28 November 2012.

Goss, K.A. and Heaney, M.T. (2010) Organizing women as women: hybridity and grassroots collective action in the 21st century. Perspectives on Politics, 8, 27-52.

Harvey, B. (2014) Are We Paying for That: Government Funding and Social Justice Advocacy. Dublin: The Advocacy Initiative.

Hochschild, A.R. (1983) The Managed Heart: Commercialization of Human Feeling.

Husso, M. and Hirvonen, H. (2012) Gendered agency and emotions in the field of care work. Gender, Work and Organization, 19, 1, 29-51.

Irish Congress of Trade Unions (ICTU) (2013) Women Organising for Decent Work. Dublin: ICTU.

Irvine, J., Lang, S. and Montoya, C. (2015) Gendered mobilizations in an expanding Europe. Paper presented at the Gender Mobilization Conference, Seattle, WA, May. 
Kantola, J. and Squires, J. (2012) From state feminism to market feminism? International Political Science Review, 33, 4, 382-400.

Keane, C., Callan, T. and Walsh, J.R. (2014) Gender Impact of Tax and Benefit Changes: a Microsimulation Approach. Dublin: Equality Authority and ESRI.

Kirby, P. and Murphy, M. (2011) Towards a Second Republic Ireland: Politics After the Celtic Tiger. London: Pluto Press.

McRobbie, A. (2009) The Aftermath of Feminism: Gender, Culture and Social Change. London: Sage.

Migrants Rights Centre Ireland (MRCI), Services Industrial Professional and Technical Union (SIPTU) and the Carers' Association (2015) Employment Guidelines for the Home Care Sector: the Workers' Perspective. Dublin: MRCI.

Motta, S., Eschle, C., Flescher Fominaya, C. and Cox, L. (2011) Introduction to Interface: special issue on feminism, women's movements and women in movements. Interface, 3, 2, 123-51.

Murphy, M.P. (2012) Irish civil society in the shadow of the Irish state. Irish Journal of Sociology, 19, 2, 173-89.

Murphy, M.P. (2014) Ireland's lone parents, social welfare and recession. Irish Community Development Law Journal, 3, 2, 6-20.

Murphy, M.P. and Loftus, C. (2014) A gendered right to social security and decent work? The debate in the context of Irish austerity. In Goldblatt, B. and Lamarche, L. (eds) Women's Right to Social Security, pp. 239-62. London: Hart.

Naples, N.A. (1992) Activist mothering: cross-generational continuity in the community work of women from lowincome urban neighborhoods. Gender and Society, 6, 3, 441-63.

National Women's Council of Ireland (NWCI) (2014) Small Steps on Child Benefit but Need for Long Term Investment in Childcare. Available online at http://www.nwci.ie/?/learn/article/small_steps_on_child _benefit_but_need_for_long_term_investment_in_childcare\#sthash.ieCeUMiH.dpuf. Last accessed 22 January 2015.

Newman, J. (2013) Spaces of power: feminism, neoliberalism and gendered labor. Social Policy, 20, 2, $200-21$.

O'Brien, A. (2014) It's a man's world: a qualitative study of the (non) mediation of women and politics on prime time during the 2011 general election. Irish Political Studies, 29, 4, 505-21.

Oireachtas (2012) Home Help and Home Care Services: Motion [Private Members] (Continued). Available online at http://oireachtasdebates.oireachtas.ie/debates\%20authoring/debateswebpack.nsf/takes/dail2012101600 050. Last accessed 21 January 2015.

One Parent Exchange Network (OPEN) (2012) Seven is too Young. Available online at www.youtube.com/watch? v=TvtKrwgblWE. Last accessed 15 March 2016.

Quinn, M. (2004) Trade unions, gender and class. Gender, Work and Organization, 11, 6, 648-67.

Robson, S. and Spence, J. (2011) The erosion of feminist self and identity in community development theory and practice. Community Development Journal, 46, 3, 288-301.

Roche, W.K., Teague, P. Coughlan, A. and Fahy, M. (2011) Human Resources in the Recession: Managing and Representing People at Work in Ireland (Executive Summary). Available online at www.ucd.ie/t4cms/Human\%20Resources\%20in\%20the\%20Recession\%20Book\%20Manuscript.pdf. Last accessed 15 March 2015.

Rubery, J. (2013) From 'women and recession' to 'women and austerity': a framework for analysis. In Karamessini, M. and Rubery, J. (eds) Women and Austerity, pp. 17-37. Abingdon: Routledge.

Sanchez Salagado, R. (2013) The Europeanization of domestic CSOs in a time of crisis. Paper presented at the Council of European Studies Conference, Amsterdam, June.

Single Parents Acting for the Rights of Our Kids (SPARK) (2013) Protest Against 2012 Budget. Available online at https://www.facebook.com/events/848238128590475/. Last accessed 21 November 2015.

Single Parents Acting for the Rights of Our Kids (SPARK) (2015) Who Are We? Available online at https: / / www. facebook.com/SPARKsingleparents/info/?tab=page_info. Last accessed 19 August 2016.

Think Tank for Action on Social Change (TASC) (2012) Towards an Equality Budget. Dublin: TASC.

Walby, S. (2011) The Future of Feminism. Cambridge: Polity Press.

Whyte, B. and Mitchell, S. (2015) Home care firms get $€ 156$ m from HSE. Sunday Business Post, 8 November, p. 16.

Woodward, A.E., Shanin, J. and Terzis, G. (2014) The impact of the crisis on civil society organizations in the EU: risks and opportunities. Open Citizenship, 4, 1, 12-22.

\section{Biographical notes}

Pauline Cullen is a Lecturer in Sociology and Politics at Maynooth University. Her research interests and publications examine the politics and social practices of civil society at the national and European Union level; the mobilization strategies of women's organizations and feminist movements; and women in political office and gender equality.

Dr Mary P. Murphy lectures in Irish Politics and Society in the Department of Sociology, Maynooth University. She has research interests in gender and social security, globalization and welfare states, activation, the politics of redistribution, and power and civil society. An active advocate for social justice and equality, she is a part-time Commissioner on the Irish Human Rights and Equality Commission. 